\title{
Effect of stony corals extracts on feeding by Acanthaster planci
}

\author{
Kazuhiro Sonoda, Valerie J. Paul \\ Marine Laboratory, University of Guam, UOG Station, Mangilao, Guam 96923
}

\begin{abstract}
The preference of the starfish Acanthaster planci (Linnaeus, 1758) for 3 species of corals which survive A. planci outbreaks (Diploastrea heliopora, Porites rus, and Coscinaraea columna), and the effects of organic and aqueous extracts of these corals on $A$. planci feeding, were investigated experimentally in the laboratory. We hypothesized that extracts of these corals deter feeding by A. planci, but instead we found no evidence that chemical defenses were produced by these stony corals against $A$. planci. In whole-coral experiments, D. heliopora and $P$. rus were consumed significantly less than Acropora aspera, a preferred coral species. Organic extracts from $D$. heliopora stimulated feeding at low concentrations, but not at higher natural concentrations compared with solvent controls. Organic extracts of $P$. rus and $C$. columna did not deter or stimulate $A$. planci feeding at low and high natural concentrations compared with controls. Aqueous extracts from all 3 nonpreferred corals tended to stimulate feeding at high concentrations relative to controls, but only aqueous extracts of $P$. rus at high concentrations significantly enhanced $A$. planci feeding. When aqueous extracts of $A$ aspera were compared with the aqueous extracts of the 3 non-preferred corals, $A$. aspera extracts were significantly preferred over $D$. heliopora and $C$. columna, but not over $P$. rus. Overall, aqueous extracts of all coral species tended to stimulate feeding by $A$. planci and most organic extracts had no effect on feeding. None of the extracts deterred $A$. planci feeding relative to controls as would be expected for extracts of chemically defended species. Some other defense appears to keep non-preferred corals from being consumed by $A$. planci, and we discuss the possibility that chemical crypsis may be one mechanism
\end{abstract}

KEY WORDS: Acanthaster planci $\cdot$ Chemical defence $\cdot$ Extracts $\cdot$ Feeding preferences $\cdot$ Stony crab

\section{INTRODUCTION}

In coral reef habitats, the crown-of-thorns starfish Acanthaster planci plays a very important role as a major predator of scleractinian corals (Birkeland \& Lucas 1990). Although $A$. planci can feed on a wide range of animals such as anemones, soft corals, and encrusting organisms (Moran 1986), field observations show that adult $A$. planci feed primarily on hard corals, and they use other food sources when scleractinian coral availability is low (Chesher 1969a). A. planci has been considered to be a specialist coralfeeder (Benson et al. 1975, Cameron \& Endean 1982, Moran 1986). Predation by $A$. planci is known for its large-scale effects on changes in species composition, trophic structure, and topography of coral reef communities (Chesher 1969a, Endean 1973, Glynn 1973,
1974, Pearson 1981, Moran 1986, Birkeland 1988). Large outbreaks of $A$. planci throughout the tropical Pacific and Indian Oceans are well documented (Chesher 1969a, b, Endean 1973, Moran 1986, Yamaguchi 1986).

Previous feeding preference experiments and field observations indicate that Acanthaster planci has dietary preferences among the corals (Birkeland \& Lucas 1990). The dietary preference of $A$. planci for certain species of corals may be influenced by defensive structures such as nematocysts (Barnes et al. 1970, Goreau et al. 1972) and colony morphology (Chesher 1969b, Ormond \& Campbell 1974, Menge 1982). A. planci feeding behavior in vivo is further influenced by environmental conditions (Birkeland \& Lucas 1990) such as wave action (Endean 1973, Ormond et al. 1973, Birkeland \& Randall 1979), the accessibility of corals 
(Barnes et al. 1970, Glynn 1976, 1985a, b), and the relative abundance and distribution of corals (Ormond et al. 1973, Glynn 1985a, b). Large colonies of pocilloporids protected by crustacean symbionts are also not preyed upon (Goreau et al. 1972, Glynn 1982a, b, 1983, 1987). However, pocilloporids without crustacean symbionts are favored prey of A. planci (Glynn 1976, 1982a, b, 1987). Acroporids are also preferred prey of A. planci (Pearson \& Endean 1969, Roads 1969, Garlovsky \& Bergquist 1970, Branham et al. 1971, Goreau et al. 1972, Nishihara \& Yamazato 1973, Ormond et al. 1976, Aziz \& Sukarno 1978, Birkeland \& Randall 1979, Colgan 1987). In contrast, the stony corals Diploastrea heliopora, Coscinaraea spp., Galaxea spp., Turbinaria spp. and Tubastrea micrantha are reported as non-preferred prey (Barnes et al. 1970, Endean \& Stablum 1973a, b, Birkeland \& Lucas 1990); however, the reasons that these corals are non-preferred prey are presently unknown.

Extracts from different species of corals are reported to elicit feeding-attraction or avoidance responses of Acanthaster planci (Brauer et al. 1970, Collins 1975b, Ormond et al. 1976). Extracts from Acropora spp. and Pocillopora spp. elicited positive feeding responses, but extracts from Porites spp. caused avoidance responses (Brauer et al. 1970). Collins (1975a) identified the substance in Fungia spp. (chemically similar to the amino acid proline) responsible for the avoidance response.

Within Guam's coral fauna, high survival rates of Coscinaraea columna, Diploastrea heliopora, and Porites rus after Acanthaster planci outbreaks have been documented (R. H. Randall \& C. E. Birkeland pers. comm.). In this study, we investigated (1) the preferences of $A$. planci for these corals that appear to survive outbreaks of $A$. planci, (2) the effects of crushed coral tissues, which eliminates morphological features of the coral, on feeding patterns of $A$. planci.; and (3) the effects of aqueous and organic extracts produced by these corals on feeding by $A$. planci.

We hypothesized that these corals survive outbreaks of Acanthaster planci because they are actively avoided by $A$. planci and that chemical defenses play an important role in the low susceptibility of these corals to predation.

\section{MATERIALS AND METHODS}

Experimental animals. Corals and Acanthaster planci were collected from various reefs around Guam. The specimens of $A$. planci varied from 20 to $30 \mathrm{~cm}$ in diameter. These were kept in outdoor flow-through seawater tanks and fed Acropora aspera, a preferred coral, for 1 to $2 \mathrm{wk}$ before the experiments to ensure that all $A$. planci were in a similar dietary condition.
A. aspera was used as a food because it is abundant and highly preferred by $A$. planci (Pearson \& Endean 1969, Roads 1969, Garlovsky \& Bergquist 1970, Branham et al. 1971, Goreau et al. 1972, Nishihara \& Yamazato 1973, Ormond et al. 1976, Aziz \& Sukarno 1978, Birkeland \& Randall 1979, Colgan 1987). In this study, we investigated organic and aqueous extracts of the following species of corals for their biological activities: (1) Diploastrea heliopora, (2) Porites rus, and (3) Coscinaraea columna.

Coral extraction. Organic extracts were obtained from corals with a 1:1 mixture of dichloromethane $\left(\mathrm{CH}_{2} \mathrm{Cl}_{2}\right)$ and methanol $(\mathrm{MeOH})$. Aqueous extracts were obtained by soaking corals in a mixture of $1: 1$ $\mathrm{MeOH}$ and deionized water. Extracts were filtered, and solvents were evaporated with a rotary evaporator. For aqueous extracts, the remaining aqueous layers were freeze dried. These extracts were stored in the freezer. All the extracts were tested within 1 mo from the time of extraction.

To quantify the yield of extracts per dry mass of tissue and per surface area of corals, about $8.0 \mathrm{~cm}^{2}$ of live coral tissue from 5 different colonies was washed with deionized water using a Water Pik (Johannes \& Wiebe 1970), and the washed tissue was freeze dried. After obtaining the dry weight, extracts were obtained from each dried tissue sample in $100 \mathrm{ml}$ of a $\mathrm{CH}_{2} \mathrm{Cl}_{2}$ / $\mathrm{MeOH}$ mixture then in a $\mathrm{MeOH} /$ deionized water mixture as described previously. The yields were expressed in $\mathrm{mg}$ of extract per coral tissue area $\left(\mathrm{cm}^{2}\right)$ and mg of extract per freeze-dried coral tissue weight (mg). Comparisons in yields among species were made by 1-way ANOVA supplemented by the StudentNewman Keuls (SNK) procedure. For the percent yield analysis, data were treated by arcsine transformation prior to ANOVA.

Overview of experimental design. To test the Acanthaster planci feeding preferences among the selected corals and their extracts, we established 6 different feeding preference trials. We first tested the preference of $A$. planci for whole corals in aquaria to see whether non-preferred corals are actually avoided by $A$. planci. The whole coral preferences were followed by experiments with crushed corals to see if morphological differences among the coral species influenced $A$. planci feeding behavior. In the next 2 set of experiments, we tested the effects of coral organic extracts (at low and high concentrations) on A. planci feeding preferences. The last 2 sets of experiments were designed to test low and high concentrations of coral aqueous extracts. In each trial, we used Acropora aspera, a preferred coral, as a control. A priori hypotheses were: (1) extracts from non-preferred corals are avoided when tested against solvent controls; (2) A. aspera controls are always preferred over non-susceptible corals. 
Feeding preference trials. All feeding preference trials were done in outdoor aquaria $(20 \times 95 \times 50 \mathrm{~cm})$ with constantly running seawater. In all feeding preference experiments, 20 Acanthaster planci were randomly selected from more than 100 stock specimens. In some cases, the same individuals were used more than once, but never in the same type of trial. The duration of each trial was $6 \mathrm{~h}$. If individuals did not make any choice in this time period, the results were not scored for that individual.

For whole-coral preference experiments, Acropora aspera and a test coral were placed approximately $25 \mathrm{~cm}$ apart at the downstream end of the tank in alternated fashion (left vs right), and one Acanthaster planci was placed at the upstream end. Corals were cut to a similar size (approximately $10 \times 10 \mathrm{~cm}$ ) at least $3 \mathrm{~d}$ prior to the trials to minimize mucus secretion. Food choice was only scored when an individual $A$. planci had spread its stomach over most of the coral. Therefore, a preference was not scored when it simply walked over the corals or touched the corals with tube feet during the trials. Results were scored as the number of $A$. planci selecting each coral, and were analyzed by a 2 -tailed binomial test (Sokal \& Rohlf 1981).

In addition to the whole corals, the crushed coral tissues were tested. The crushed coral tissues were collected by scraping about $25 \mathrm{~cm}^{2}$ of living surface area from corals. The crushed coral tissues were mixed with $2.5 \mathrm{~g}$ of carrageenan in $100 \mathrm{ml}$ of deionized water. After the carrageenan mixture hardened, it was cut. into small cubes $(2 \times 2 \times 2 \mathrm{~cm})$. About $3 \mathrm{~g}$ of the crushed coral tissue (including some exoskeleton) was present in each carrageenan cube. In the first set of trials, crushed coral cubes were compared with control cubes containing only carrageenan and deionized water. For the second set of trials, crushed coral cubes were compared with control cubes that incorporated the same amount of crushed Acropora aspera tissue. These cubes and small pieces (cut to $2 \mathrm{~cm}$ in length $3 \mathrm{~d}$ prior to the trials) of preferred coral $A$. aspera were wrapped together with gauze, which was held with safety pins around the coral. These gauze-wrapped corals and carrageenan cubes were placed $25 \mathrm{~cm}$ apart on feeding platforms $(50 \mathrm{~cm}$ long $3 / 4$ inch $(=19 \mathrm{~mm})$ diameter
PVC pipe). Determination of $A$. planci preferences were made when an individual spread its stomach over a gauze-wrapped coral. Results were scored and analyzed with a binomial test in the same way as in the whole-coral preference experiments

For coral-extract (organic soluble) preference experiments, extracts from corals were dissolved in ether and coated at a concentration of $0.45 \mathrm{mg} \mathrm{cm}^{-2}$ and $2.7 \mathrm{mg}$ $\mathrm{cm}^{-2}$ on gauze $(7.5 \times 7.5 \mathrm{~cm})$. Controls were coated with ether only. In addition to these high and low natural concentrations (Table 1), organic extracts were also tested at $1 \mathrm{mg} \mathrm{cm}{ }^{-2}$, with organic extract of Acropora aspera used as a control to compare interspecific organic extract preferences. Small pieces ( $2 \mathrm{~cm}$ in length) of A. aspera were wrapped with the chemically coated gauze, then offered to A. planci as described above.

Aqueous extracts from corals were tested slightly differently from organic extracts because these readily dissolve in seawater and can then be lost to solution during the experiment. To minimize this loss, aqueous extracts were tested in the same way as the crushed coral tissues by incorporating them into carrageenan cubes. Because of their solubilities into seawater, it was very difficult to quantify natural concentrations of aqueous extracts in laboratory trials; therefore they were tested at 1 and $5 \%$ mass/volume concentrations to cover a wide range of natural concentrations (Table 1). The control cubes contained only carrageenan and distilled water. Additionally, aqueous extracts were also tested at a $2 \% \mathrm{~m} / \mathrm{v}$ concentration compared with Acropora aspera aqueous extracts at $2 \% \mathrm{~m} / \mathrm{v}$ as a control. These cubes and small pieces ( $2 \mathrm{~cm}$ in length) of $A$. aspera were wrapped together with gauze, then offered to $A$. planci as described above. New coral extracts were used in all of the organic and aqueous extracts trials.

\section{RESULTS}

\section{Coral extraction}

Based on quantitative extraction, Acropora aspera had on average a slightly higher yield of organic extract per freeze-dried tissue mass than the non-

Table 1. Natural concentrations of extracts in corals. Values reported are mean \pm 1 SD. $N=5$ for each species. Values are reported as yield per surface area $\left(\mathrm{mg} \mathrm{cm}^{-2}\right.$ tissue) and \% yield per freeze-dried tissue dry mass. Significant differences among means for different species $(p<0.05$, SNK) are indicated by superscript letters for each column

\begin{tabular}{|c|c|c|c|c|}
\hline \multirow[t]{2}{*}{ Species } & \multicolumn{2}{|c|}{ Organic } & \multicolumn{2}{|c|}{ Aqueous } \\
\hline & $\mathrm{mg} \mathrm{cm} \mathrm{cm}^{-2}$ tissue & $\%$ yield & $\mathrm{mg} \mathrm{cm}^{-2}$ tissue & $\%$ yield \\
\hline Diploastrea heliopora & $2.6 \pm 1.4^{d}$ & $10.0 \pm 5.1^{\mathrm{a}}$ & $8.9 \pm 4.9^{\mathrm{ab}}$ & $32.0 \pm 9.8^{a}$ \\
\hline Porites rus & $1.8 \pm 1.0^{\circ}$ & $7.5 \pm 3.7^{\mathrm{a}}$ & $12.5 \pm 3.7^{b c}$ & $53.4 \pm 6.4^{b}$ \\
\hline Coscinaraea columna & $1.5 \pm 0.4^{a}$ & $4.6 \pm 1.2^{\circ}$ & $17.2 \pm 5.4^{c}$ & $51.6 \pm 13.3^{b}$ \\
\hline Acropora aspera & $1.5 \pm 0.2^{d}$ & $16.8 \pm 4.2^{b}$ & $5.0 \pm 1.2^{a}$ & $53.5 \pm 1.7^{b}$ \\
\hline
\end{tabular}


susceptible corals. However, it had lower average concentrations of organic and aqueous extracts per surface area (Table 1). Among non-susceptible corals, Diploastrea heliopora tended to have high concentrations of organic extract per area as well as per freezedried tissue mass (Table 1). D. heliopora had the lowest yield of aqueous extract per tissue mass while the aqueous extracts of Porites rus, Coscinaraea columna, and $A$. aspera accounted for more than $50 \%$ of their freeze-dried tissue mass and did not significantly differ from each other (Table 1).

\section{Whole-coral preference trials}

In the whole-coral preference experiment, Acropora aspera was preferred in most cases (Table 2, Fig. 1). A. aspera was preferred over Porites rus and Diploastrea heliopora $(\mathrm{p}=0.004$ and $\mathrm{p}=0.041$ respectively); however, there were no significant preferences between Coscinaraea columna and A. aspera ( $p=0.332$ ).

Table 2. Acanthaster planci. Preferences for whole-coral colonies. Values reported are number of individuals preferring each species in 3 separate choice tests. P-values were determined by 2 -tailed binomial tests

\begin{tabular}{|lcc|}
\hline Species & No. preferring & $\mathrm{p}$ \\
\hline Diploastrea heliopora & 5 & 0.041 \\
Acropora aspera & 15 & \\
Porites rus & 2 & 0.004 \\
Acropora aspera & 15 & \\
Coscinaraea columna & 6 & 0.332 \\
Acropora aspera & 11 & \\
\hline
\end{tabular}

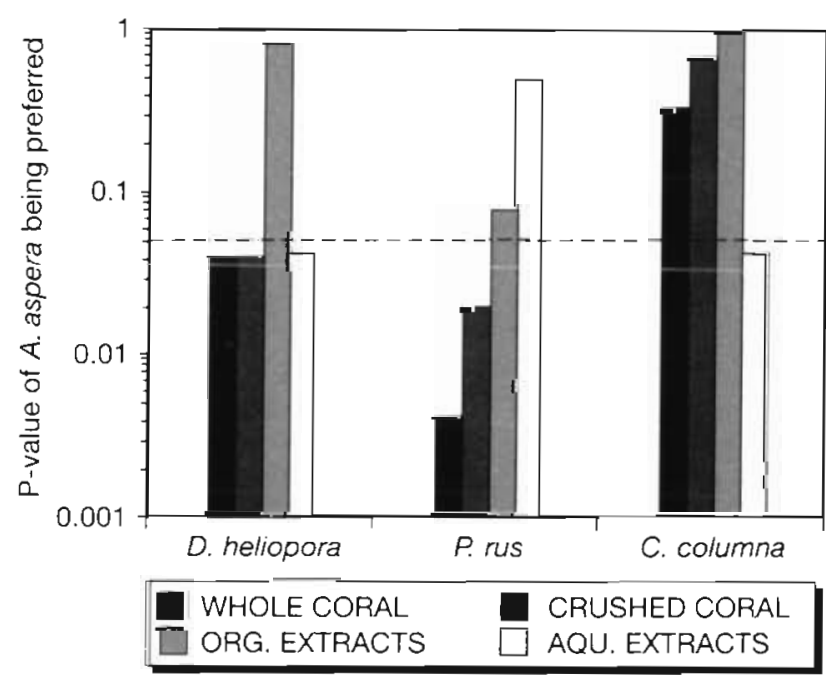

Fig. 1. Acanthaster planci. Summary of preferences on Acropora aspera and 3 test corals. Dotted line indicates p-value of 0.05

\section{Crushed coral tissue preference trials}

All of the crushed coral tissues appeared to stimulate behavior when tested against plain controls (Table 3 ). Porites rus stimulated feeding behavior the most $(p=0.004)$ among the tested corals. (These data were similar to the $5 \%(\mathrm{~m} / \mathrm{v})$ aqueous extract data; Table 7$)$.

Crushed coral tissues were also tested against crushed Acropora aspera as a control. A. aspera stimulated feeding significantly when compared with Diploastrea heliopora and Porites rus (Table 4, Fig. 1). These results were similar to the whole-coral preference tests (Table 2).

Table 3. Acanthaster planci. Preferences for crushed coral tissue. Derivation of values and determination of $p$-values are the same as in Table 2

\begin{tabular}{lcc}
\hline Species & No. preferring & $\mathrm{p}$ \\
\hline Diploastrea heliopora & 13 & 0.167 \\
Control & 6 & \\
Porites rus & 16 & 0.004 \\
Control & 3 & \\
Coscinaraea columna & 13 & 0.096 \\
Control & 5 & \\
\hline
\end{tabular}

Table 4. Acanthaster planci. Preferences for crushed coral tissue with crushed Acropora aspera as the control. Derivation of values and determination of $\mathrm{p}$-values are the same as in Table 2

\begin{tabular}{|lcc|}
\hline Species & No. preferring & $\mathrm{p}$ \\
\hline Diploastrea heliopora & 5 & 0.041 \\
Acropora aspera & 15 & \\
Porites rus & 4 & 0.019 \\
Acropora aspera & 15 & \\
Coscinaraea columna & 8 & 0.648 \\
Acropora aspera & 11 & \\
\hline
\end{tabular}

\section{Organic extract preierence trials}

Organic extracts were tested at a concentration of $0.45 \mathrm{mg} \mathrm{cm}^{-2}$ and $2.7 \mathrm{mg} \mathrm{cm}^{-2}$ to cover a range of natural concentrations found in the 4 corals (Table 1 ). Most organic extracts at low concentration $10.45 \mathrm{mg}$ $\mathrm{cm}^{-2}$ ) appeared to stimulate feeding behavior of Acanthaster planci (Table 5). However, only the Diploastaea heliopora extract significantly stimulated feeding behavior, and the extract from Coscinaraea columna did not affect feeding. When the extract concentration was increased to a $2.7 \mathrm{mg} \mathrm{cm}^{-2}$ level, all test results became insignificant (Table 5). The small size of the tanks and location of highly concentrated extracts 
Table 5. Acanthaster planci. Preferences for coral organic extract at $0.45 \mathrm{mg} \mathrm{cm}^{-2}$ and $2.7 \mathrm{mg} \mathrm{cm}^{-2}$ concentration. Values reported are number of individuals preferring each coral extract in 3 separate choice tests. p-values were determined by 2 -tailed binomial tests. No. pref.. number preferring

\begin{tabular}{|c|c|c|c|c|}
\hline \multirow[t]{2}{*}{ Species } & \multicolumn{2}{|c|}{$0.45 \mathrm{mg} \mathrm{cm}^{-2}$} & \multicolumn{2}{|c|}{$2.7 \mathrm{mg} \mathrm{cm}^{-2}$} \\
\hline & No. pref. & $p$ & No. pref. & $\mathrm{p}$ \\
\hline Diploastrea heliopora & 12 & \multirow{2}{*}{0.035} & 7 & \multirow{2}{*}{1.000} \\
\hline Control & 3 & & 6 & \\
\hline Porites rus & 12 & \multirow{2}{*}{0.238} & 13 & \multirow{2}{*}{0.167} \\
\hline Control & 6 & & 6 & \\
\hline Coscinaraea columna & 8 & \multirow{2}{*}{0.502} & 6 & \multirow{2}{*}{1.000} \\
\hline Control & 12 & & 5 & \\
\hline
\end{tabular}

adjacent to control corals potentially affected the ability of $A$. planci to distinguish between control and treated gauze-wrapped corals.

When organic extracts were tested with Acropora aspera organic extract as the control, there was no significant difference between the number of Acanthaster planci choosing $A$. aspera and Diploastrea heliopora or Coscinaraea columna. However, the organic extract of Porites rus showed a trend of being not preferred $(p=0.077)$ when tested against $A$. aspera organic extract (Table 6, Fig. 1).

Table 6. Acanthaster planci. Preferences for coral organic extract at $1 \mathrm{mg} \mathrm{cm}^{-2}$ concentration with $1 \mathrm{mg} \mathrm{cm}^{-2}$ Acropora aspera organic extract as a control. Derivation of values and determination of $p$-values are the same as in Table 2

\begin{tabular}{|lcc|}
\hline Species & No. preferring & $p$ \\
\hline Diploastrea heliopora & 8 & 0.814 \\
Acropora aspera & 10 & \\
Porites rus & 4 & 0.077 \\
Acropora aspera & 12 & \\
Coscinaraea columna & 9 & 1.000 \\
Acropora aspera & 10 & \\
\hline
\end{tabular}

\section{Aqueous extracts preference trials}

Aqueous extracts were tested at $1 \%$ (mass/volume) level and $5 \%(\mathrm{~m} / \mathrm{v})$. At low concentrations (1\%), there were no significant feeding effects (Table 7). However, when the concentration was increased to a $5 \%$ level, Diploastrea heliopora and Porites rus aqueous extracts seemed to stimulate feeding behavior (Table 7), especially aqueous extracts from $P$. rus $(p=0.004)$.

The aqueous extracts were also tested with Acropora aspera aqueous extract as a control. A. aspera significantly stimulated feeding compared with Diploastrea
Table 7. Acanthaster planci. Preferences for coral aqueous extract at $1 \% \mathrm{~m} / \mathrm{v}$ and $5 \% \mathrm{~m} / \mathrm{v}$ concentration. No. pref.: number preferring. Derivation of values and determination of p-values are the same as in Table 5

\begin{tabular}{|lrcrcr|}
\hline \multirow{2}{*}{ Species } & \multicolumn{2}{c}{$1 \% \mathrm{~m} / \mathrm{v}$} & \multicolumn{3}{c|}{$5 \% \mathrm{~m} / \mathrm{v}$} \\
& No. pref. & $\mathrm{p}$ & No. pref. & $\mathrm{p}$ \\
\hline Diploastrea heliopora & 8 & 0.814 & 12 & 0.238 \\
Control & 10 & & 6 & \\
Porites rus & 6 & 0.454 & 14 & 0.004 \\
Control & 10 & & 2 & \\
Coscinaraea columna & 11 & 0.332 & 11 & 0.332 \\
Control & 6 & & 6 & \\
\hline
\end{tabular}

Table 8. Acanthaster planci. Preferences for coral aqueous extract at $2 \% \mathrm{~m} / \mathrm{v}$ concentration with $2 \% \mathrm{~m} / \mathrm{v}$ Acropora aspera aqueous extract as a control. Derivation of values and determination of p-values are the same as in Table 5

\begin{tabular}{|lcc|}
\hline Species & No. preferring & $\mathrm{p}$ \\
\hline Diploastrea heliopora & 5 & 0.041 \\
Acropora aspera & 15 & \\
Porites rus & 8 & 0.503 \\
Acropora aspera & 12 & \\
Coscinaraea columna & 5 & 0.041 \\
Acropora aspera & 15 & \\
\hline
\end{tabular}

heliopora and Coscinaraea columna. However, compared with Porites rus aqueous extract, there was no significant difference (Table 8, Fig. 1).

\section{DISCUSSION}

Feeding preferences of Acanthaster planci for 3 species of non-susceptible corals did not provide direct evidence of chemical defenses in these stony corals. However, laboratory experiments indicate that $A$. planci has significant feeding preferences for some corals and their extracts. As whole corals, Diploastrea heliopora and Porites rus were significantly less susceptible to A. planci than Acropora aspera (Table 2). Interestingly, under laboratory conditions, A. planci showed no difference in preference between Coscinaraea columna, which is known as a non-favored prey (Birkeland \& Lucas 1990), and A. aspera. When these corals were crushed and incorporated into the carrageenan cubes, then wrapped by gauze to eliminate possible differences in micromorphology and nematocysts among them, the patterns of feeding preferences (Table 4) remained identical to those of whole coral preference tests (Table 2). This result suggests that $A$. planci feeding preference 
patterns for these coral species are determined neither by coral micro-morphology nor type of nematocysts present in these 3 corals, in contrast to previously reported studies which suggest that coral morphology and nematocysts may affect feeding preferences of $A$. planci (Barnes et al. 1970, Goreau et. al. 1972, Chesher 1969b, Menge 1982). However, colony sizes used in this experiment were relatively smaller than most colonies in the field. Full-size coral colonies might have different effects on feeding patterns in the field, since growth form and gross morphology can affect feeding patterns, but it is almost impossible to conduct laboratory preference trials with intact coral colonies.

Since nematocyst effectiveness was never tested directly in the trials, the possibility of defense by nematocysts cannot be eliminated entirely. However, results of our experiments suggest that feeding preference patterns are likely determined by chemical stimulants produced by these corals. Chemical extracts of live corals have long been known to induce movement and feeding responses of Acanthaster planci (Brauer et al. 1970, Collins 1974, Hanscomb 1976). In this study, almost all types of coral extracts (aqueous and organic) or crushed corals stimulated $A$. planci feeding behavior and in most cases acted as attractants.

Tests of organic extracts from these corals compared with solvent controls, indicate that extracts have no effect or are slightly attractant toward Acanthaster planci. When these organic extracts were tested with Acropora aspera organic extract as controls, there were no significant differences in feeding preferences between extracts from 2 non-susceptible corals (Diploastrea heliopora and Coscinaraea columna) and $A$. aspera. The only exception to this was the organic extract from Porites rus, which tended to be less preferred than the $A$. aspera extract ( $p=0.077$; Fig. 1). Based on these data, organic extracts from $D$. heliopora, $C$. columna and $A$. aspera do not strongly affect $A$. planci feeding behavior.

Most of the aqueous extracts at a $5 \%$ mass/volume concentration from these corals tended to be attractants, especially Porites rus extract $(p=0.004)$. Tests of these extracts with Acropora aspera aqueous extract as a control showed that Acanthaster planci significantly preferred $A$. aspera aqueous extracts over Diploastrea heliopora and Coscinaraea columna $(p=0.041$ for each) but not over $P$. rus extract (Fig. 1). This result can be explained by strong feeding attraction triggered by $P$. rus aqueous extracts ( $p=0.004$; Table 6 ) acting to offset the attraction caused by $A$. aspera aqueous extracts (Table 7 ).

This may indicate that some particular chemical components in the aqueous extracts are responsible for attracting Acanthaster planci. The degree of attraction. toward $A$. planci may be influenced by quantities or types of these attractant chemicals in the corals. Such chemicals are possibly water-soluble proteins, amino acids, carbohydrates or other organic molecules. It is also likely that the quantity or quality of the attractant chemicals varies among coral species. Therefore, we cannot derive a generalized conclusion simply based on extracts yields. Collins (1975a) and Hanscomb (1976) reported that both high and low molecular weight fractions are responsible for eliciting feeding responses. Identifying the chemical components of coral extracts that are most responsible for $A$. planci feeding preference could be done by separating each extract into fractions by chromatographic methods and testing fractions in a series of feeding preference trials until purification of the active components is achieved.

Mechanisms responsible for high survival rates of some non-susceptible corals and avoidance of predation by Acanthaster planci are still unknown. Based on our results, chemical defenses do not seem to be involved in this process. Consequently, we cannot say with certainty what factor(s) prevent $A$. planci from feeding on some corals. Methodological constraints of working with full size coral colonies in the laboratory prevent us from ruling out the effects of colony morphology and growth form. Also, because $A$. planci fed on Acropora aspera in holding tanks prior to the experiments, this previous diet history may have affected the preference experiments. However, even given these limitations, a possible explanation for this phenomena may be derived by analyzing preference trial data. We suggest that $A$. planci may select and feed on prey according to the strength of attractant chemical stimulants. Diploastrea heliopora and Porites rus may not produce potent feeding stimulants, and when undisturbed, may emit few or no attractant chemicals that initiate feeding behavior of $A$. planci. On the other hand, other corals such as $A$. aspera may secrete more noticeable chemical stimulants which attract $A$. planci. When these non-susceptible corals are crushed or chemically extracted, the chemical stimulants responsible for A. planci feeding behavior are enhanced. As a result they become preferred over controls that do not contain coral extracts.

Acanthaster planci locates prey by means of chemosensory attraction (Ormond et al. 1973). Therefore chemical stimulants play a very important role in the predator-prey relationship of $A$. planci and stony corals. In the field, A. planci are often attracted to damaged corals or colonies already preyed upon by other A. planci (Ormond et al. 1973, Sloan \& Campbell 1982). This feeding behavior also suggests that quantities and strengths of chemical stimulants in the environment are very important in determining dietary preferences.

Non-susceptible corals such as Diploastrea heliopora, Porites rus or Coscinaraea columna possibly 
avoid Acanthaster planci predation by not producing and releasing chemical attractants to the immediate environment; hence becoming chemically cryptic. For survival of stony corals, avoiding detection by being chemically cryptic to the potential predator may be more efficient than deterring predators with chemical defenses.

Acknowledgements. We thank Dr S. Amesbury, Dr C. Birkeland, Dr R. Bradbury, Dr J. Fernandez, Dr B. Lassig, Dr E. Matson, Dr S. Nelson, Dr G. Paulay, Dr S. Pennings, Mr R. Randall, Dr R. Richmond and Mr B. Smith for their valuable comments, criticisms, and assistance which helped to improve this work. We also thank S. Quenga for proof-reading many drafts of this manuscript and graduate students D. Norris, F. Te, P. Schupp, A. Kerr, K. Meyer and D. Hopper for helping us throughout this project. This research was facilitated by NIH grant GM 38624 to V. J. Paul. This is contribution no. 341 of the University of Guam Marine Laboratory.

\section{LITERATURE CITED}

Aziz, A., Sukarno (1978). Preliminary observation on Iiving habits of Acanthaster planci (Linnaeus) at Pulau Tikus. Seribu Islands. Mar. Res. Indonesia 17: 121-132

Barnes, D. J., Brauer, R. W., Jordan, M. R. (1970). Locomotory response of Acanthaster planci to various species of coral. Nature 228: 342-343

Benson, A. A., Patton, J. S., Field, C. E. (1975). Wax digestion in crown-of-thorns starfish. Comp. Biochem. Physiol. 52(B): $339-340$

Birkeland, C. (1988). Second-order ecological effects of nutrient input into coral communities. Galaxea 7: 91-100

Birkeland, C., Lucas, J. S. (1990). Acanthaster planci: Major Management Problem of Coral Reefs. CRC Press Inc., Florida, p. 116-119

Birkeland, C., Randall, R. H. (1979). Report on the Acanthaster planci (Alamea) studies on Tutuila, American Samoa. Report submitted to the Director, Office of Marine Resources, Government of American Samoa

Branham, J. M., Reed, S. A., Bailey, J. H., Caperron, J. (1971). Coral-eating sea stars Acanthaster planci in Hawaii Science 172: 1155-1557

Brauer, R. W., Jordan, M. R., Barnes, D. J. (1970). Triggering of the stomach eversion reflex of $A$. planci by coral extract. Nature 228: $344-346$

Cameron, A. M., Endean, R. (1982). Renewed populations outbreaks of a rare and specialized carnivore (the starfish Acanthaster plancil in a complex high-diversity system (the Great Barrier Reef). Proc. 4th int. coral Reef Symp. 2 593-596

Chesher, R. H. (1969a). Destruction of Pacific corals by the sea star Acanthaster planci. Science 165: 280-283

Chesher, R. H. (1969b). Acanthaster planci: impact on Pacific coral reefs. Final Report to U.S. Department of the Interior, Westinghouse Research Laboratories, Pittsburgh

Colgan, M. W. (1987). Coral reef recovery on Guam (Micronesia) after catastrophic predation by Acanthaster planci. Ecology 68: 1592-1605

Collins, A. R. S. (1974). Biochemical investigation of two responses involved in the feeding behavior of Acanthaster planci (L.). I. Assay methods and preliminary results. J. exp. mar. Biol. Ecol. 15: 173-184
Collins, A. R. S. (1975a). Biochemical investigation of two responses involved in the feeding behavior of Acanthaster planci (L.). II. Isolation and characterization of chemical stimuli. J. exp. mar Biol. Ecol. 17: 69-86

Collins, A. R. S. (1975b). Biochemical investigation of two responses involved in the feeding behavior of Acanthaster planci (L.). III. Food preferences. J. exp. mar. Biol. Ecol. 17: $87-94$

Endean, R. (1973). Population explosions of Acanthaster planci and associated destruction of hermatypic corals in the Indo-west Pacific region. In: Jones, O. A., Endean, R., (eds.) Biology and geology of coral reefs, Vol. II, Biology 1. Academic Press, New York, p. 389-438

Endean, R., Stablum, W. (1973a). A study of some aspects of the crown-of-thorns starfish (Acanthaster planci) infestations of reefs of Australia's Great Barrier Reef. Atoll Res. Bull. 167: 1-77

Endean, R., Stablum, W. (1973b). The apparent extent of recovery of reefs of Australia's Great Barrier Reef devastated by the crown of thorns starfish (Acanthaster plancl). Atoll Res. Bull. 168: 1-40

Garlovsky, D. F., Bergquist, A. (1970). Crown-of-thorns starfish in Western Samoa. South Pacif. Bull. 20: 47-49

Glynn, P. W. (1973). Acanthaster effect on coral reef growth in Panama. Science 180: 504-506

Glynn, P. W. (1974). The impact of Acanthaster on corals and coral reefs in the Eastern Pacific. Environ. Conserv. 1 $295-304$

Glynn, P. W. (1976). Some physical and biological determinants of coral community structure in the eastern Pacific. Ecol. Monogr. 46: 431-456

Glynn, P. W. (1982a). Acanthaster population regulation by a shrimp and a worm. Proc. 4th int. coral Reef Symp. 2: $607-612$

Glynn, P. W. (1982b). Individual recognition and phenotypic variability in Acanthaster planci (Echinodermata: Asteroidea). Coral Reefs 1: 89-94

Glynn, P. W. (1983). Increased survivorship in corals harboring crustacean symbionts. Mar. Biol. Lett. 4: 105-111

Glynn, P. W. (1985a). El Niño-associated disturbance to coral reefs and post disturbance mortality by Acanthaster planci. Mar. Ecol. Prog. Ser. 26: 295-300

Glynn, P. W. (1985b). Corallivore population sizes and feeding effects following El Niño (1982-1983) associated coral mortality in Panama. Proc 5th int. coral Reef Congr. 4: 183-188

Glynn, P. W. (1987). Some ecological consequences of coralcrustacean guard mutualism in the Indian and Pacific oceans. Symbiosis 4 : 301-324

Goreau, T. F., Lang, J. C., Graham, E. A., Goreau, P. D. (1972). Structure and ecology of the Saipan reefs in relation to predation by Acanthaster planci (Linnaeus). Bull. mar. Sci. 22: $113-152$

Hanscomb, N. J., Bennett, J. P., Harper, G. (1976). Biochemical stimuli for feeding in Acanthaster planci (L.). J. exp. mar. Biol. Ecol. 22: 193-197

Johannes, R. E., Wiebe, W. J. (1970). Method for determination of coral tissue biomass and composition. Limnol Oceanogr. 15: 822-824

Menge, B. A. (1982). Effects of feeding on the environment: Asteroidea. In: Jangoux, M., Lawrence, J. M. (eds.) Echinoderm nutrition, Chap. 25. Balkema, Rotterdam, p. $521-551$

Moran, P. J. (1986). The Acanthaster phenomenon. Oceanogr. mar. Biol. A. Rev. 24: 379-480

Nishihara, M., Yamazato, K. (1973). Brief survey of Acanthaster planci in Sesoko Island and its vicinity, Okinawa. Tech. 
Rep. Sesoko Mar. Sci. Lab. Univ. Ryukyus 2: 17-33

Ormond, R. F. G., Campbell, A. C. (1974). Formation and breakdown of Acanthaster planciaggregations in the Red Sea. Proc. 2nd int. coral Reef Symp. 1. 595-619

Ormond, R. F. G., Campbell, A. C., Head, S. H., Moore, R. J. Rainbow, P. R., Saunders, A. P. (1.973). Formation and breakdown of aggregations of the crown-of-thorns starfish. Acanthaster planci (L.). Nature 246: 167-169

Ormond, R. F. G., Hanscomb, N. J., Beach, D. H. (1976). Food selection and learning in the crown-of-thorns starfish, Acanthaster planci (L.). Mar. Behav. Physiol. 4: 93-105

Pearson, R. G. (1981). Recovery and recolonization of coral reefs. Mar. Ecol. Prog. Ser. 4: 105-122

This article was presented by C. Birkeland, Guam
Pearson, R. G., Endean, R. (1969). A preliminary study of the coral predator Acanthaster planci (L.) (Asteroidea) on the Great Barrier Reef. Fish. Notes QId. 3: 27-55

Roads, C. H. (1969). Quest to the Red Sea coral reefs. Geogr. Mag., Lond. 41: 524

Sloan, N. A., Campbell, A. C. (1982). Perception of food, In: Jangoux, M., Lawrence, J. M. (eds.) Echinoderm nutrition, Chap. 1. Balkema, Rotterdam, p. 3-23

Sokal, R. R., Rohlf, F. J. (1981). Biometry, 2nd edn. W. H. Freeman \& Co., New York, p. 70-78

Yamaguchi, M. (1986). Acanthaster planci infestations of reefs and coral assemblages in Japan: a retrospective analysis of control efforts. Coral Reefs 5: 23-30

Manuscript first received: January 13, 1993

Revised version accepted: July 26, 1993 